\title{
A Study of Relationship Between Rewards and Productivity in Private Higher Institutions, Sarawak
}

\author{
Lau Hui Lin*1, Yoeng Shun Rong ${ }^{2}$, and Wong Kee Hook ${ }^{3}$ \\ ${ }^{1,2,3}$ Department of Business Administration, School of Business and Management \\ University of Technology Sarawak \\ *Corresponding author: lauhuilin@ucts.edu.my
}

\begin{abstract}
This paper provides only a perspective study but not a definite findings from quantitative evidence on how rewards can affect the productivity in the higher institutions located in middle region of Sarawak. While there have been considerable research investigating rewards and productivity over few decades ago, but very few have focused on higher institutions in Sibu, Sarawak. Thus, there is an imperative for this research in this area, especially when Sarawak state government has been gearing a full efforts to transform the state into a high economy sate in year 2025. Hence, the development of strong and productive workforce is primarily important to support the government effort to achieve the direction in the next few years. The main objective of this paper is to examine and review the reward factors associated with productivity. The study entails an empirical study with a survey questionnaires administered to 197 employees of 4 higher institutions in Sibu, Sarawak. The questionnaire consisted of the profile such as gender, education background, current role, years of working experience, and perceptions of employees towards reward on productivity in the institutions they were working with. The findings indicated the employees' perceptions towards intrinsic reward and productivity was significant and moderately high ( $\mathrm{r}$-value $=0.3-0.8, \mathrm{p}<0.01$ ) as compare to extrinsic rewards ( $\mathrm{r}$-value $=0.2-0.8, \mathrm{p}<0.01)$. The research further found that working condition, type of intrinsic reward is considered as the highest contributor to the productivity while promotion and recognition were found to be the lowest contributor to productivity. Our data also confirms that high levels of productivity are associated with intrinsic rewards. Hence, institutions of higher learning should work closely with employees in order to improve the working conditions especially the working relationship. This would ultimately contributing to the high performance and productivity of the institutions as well as economic and social development in Sarawak.
\end{abstract}

Keywords: Benefits, Extrinsic rewards, Intrinsic Rewards, Productivity, Work Content, Working Condition

\section{Introduction}

Sarawak government has been gearing a full efforts to transform the economy in year 2025 in order to bring the state to a high level of industry growth and therefore, the development of strong and productive workforce is primarily important to support the government effort to achieve the direction. The education industry is becoming one of the major players in the high level of industry growth in line with Sarawak's vision and 


Submitted: 24 July $2021 \quad$ Accepted: 28 September $2021 \quad$ Published: 31 December 2021
commitment in establishing a world class institutions of higher learning to spearhead the development and production of technical human resource for Sarawak Corridor of Renewable Energy (SCORE). With SCORE, it is able to attract around an estimated RM25 billions of investment to the state. Therefore, more academic and technical qualification would be needed to meet the demand of state industries by year 2030. In addition, Sibu is one of the main gateway to SCORE and higher institutions in Sibu plays a crucial part to ensure that graduate are equipped with the knowledge and skills required by the industries within SCORE since higher institutions are here to complement the growth and fulfill the human resource and industrial needs of SCORE.

Many organizations have now recognized that human resources play an important role in gaining profit advantage in today's highly competitive global business environment. While all aspects of human resources are important, employees' retention continues to be one of the essential Human Resource Management activity that helps organizations in their quest to achieve their goals and objectives (Mello, 2014). Reducing employees' turnover is a very crucial issue where no companies can enjoy and sustain their success until they deal with it efficiently and successfully (Ongori, 2008). According to Walters, Bamidele, Emmanuel, Nwanneka, and Bennedict (2019), employee places a great value on different rewards given to them by their employers and this has a significant impact on their performance and reduce turnover. Turnover also has a lot of negative effects on productivity, product and service quality as well as profitability. The expenses needed for new employees is high and skilled employees are very difficult to find, and replacing turnover employees can be more expensive (Boyens, 2007). Moreover, Cappelli (2008) also believes that retaining the organizations' valuable employees has been very challenging for many organizations. In addition, research estimations indicate that recruiting and training new employees cost approximately 50 percent of the workers' annual salary (Johnson, Griffeth, \& Griffin, 2000).

According to Rollinson (2008), the basic motivation to enter into a relationship with anyone or any organization is the expectation of obtaining rewards. He further explains that employees need to feel and perceive support from their employer to achieve their potential in service. Furthermore, Thomas and Ganster (1995) contended that organizational support is positively related to job satisfaction. Moreover, Ugboro and Obeng (2000) also found that employees who feel supported show better psychological well-being, higher job satisfaction and better performance. Additionally, Rhoades, and Eisenberger (2002) observed that there is moderately strong relationship between support and job satisfaction. When employees are motivated by a good reward, it will lead to higher productivity in an organization in terms of gaining profits. In return, organizations are able to success and achieve goals and achieve a competitive advantage over other competitors.

Workers' productivity refers to the amount of output produced per working hour. High productivity reflects a high amount of output production within a short working hour. According to Zunnoorain, Nasir, and Sharif (2014), productivity is influenced by 97.5 percent through independent variables such as job satisfaction and reward system. Productivity is commonly defined as a ratio between the output volume and the input volume. In other words, it measures the efficiency of the production inputs, such as labor and capital, are being used in an economy to produce a given level of output. Productivity is the ultimate engine of growth in global economy and raising productivity is therefore a fundamental challenge for countries going forward (OECD, 1995). When 

development of the country.

According to Kolbenschlag (2014), there are three ways that can make employees to become more productive. The first method is through creating unique and rewarding opportunities. The second method is to maintain a balance of collaboration. Finally, the last method is to ensure the workplace is suitable for workers to perform well. Creating unique and rewarding opportunities is the best way to motivate the employee in the workplace. When employee are motivated, employees will satisfy to work hard and thus increases the productivity in the organizations.

\section{Problem Statement}

An increase of private education institutions in the state has contributed to the economic and social development of the state. However, the development is largely depends on the qualified and competent staff of the higher education insitutions. According to Akhtar, Aamir, Khurshid, Abro, and Hussain (2015), higher educational institutions are finding it hard to retain competent and qualified human resource in the face of competition from the industry. Retention is becoming a big dilemma for developing countries. Furthermore, there is lack of empirical research on employee productivity in private education institutions particulary from the middle region of Sarawak. Moreover, higher education institutions in the country are increasing competititive and it is very important to determine the employee productivity and committment in an effective manner to ensure they will continue provide high quality academic services and also reduce the turnover as many of them prefer to work in other places due to high and more attractive rewards been offered. The present scenario can affect the performance of the existing institutions due to the shortage of good and talented employees since most of the employees will leave for better reward system. In short, employees are considered as key resources in organizations and they can assist their organizations to gain more profits by good performance and productivity. The success of the organizations depends on the employee performance. For instance, when employees are not well performed, it will cause huge lost to the organizations. Therefore, every organization should develop strategies that strengthen the work environment and increases the employee's morale and employee's job satisfaction to enhance employee retention, which ultimately results in high profits, customer satisfaction, as well as customer retention (Irabor \& Okolie, 2019)

\section{Research Objective}

The main objective of this study is to examine the type of rewards which is important in the private higher institutions located in Sibu and suggesting for more conducive working environment and increased performance and productivity.

\section{Research Questions}

i. Which types of rewards are important at the higher institutions located in Sibu?

ii. How each type of intrinsic rewards (recognition, work content, working condition) is respectively correlated with productivity?

iii. How each type of extrinsic rewards (bonus payment, benefits, promotion) is respectively correlated with productivity? 
iv. Which type of rewards will strongly affect employee productivity?

v. What are the relationship between independent variables and dependent variables?

\section{Specific Objectives}

i. To investigate the different types of rewards of the higher institutions located in Sibu.

ii. To examine how each type of intrinsic rewards (recognition, work content, working condition) is respectively correlated with productivity.

iii. To examine each type of extrinsic rewards (bonus payment, benefits, and promotion) is respectively correlated with productivity.

iv. To investigate which type of rewards will affect productivity

\section{Significance of the study}

This study is to ascertain which types of rewards, extrinsic rewards or intrinsic rewards has more significant effect to improve the productivity in high education institutions in Sibu, Sarawak. Many organizations relatively focus more on monetary and bonus rewards in order to improve productivity and retain employees. Therefore, the results of the study is able to provide some useful information for the top management of the institutions and help them to come out with appropriate form of rewards to enhance employee productivity. In view of that, organizations need to do all their best to retain a good and talented employees. Therefore, one of the effective ways to retain a good employee is to give rewards. When employees are satisfied with the rewards, they will commit their times to work for a better return and able to help their organizations by improving the productivity and profit. On top of that, giving rewards to the employees can help to reduce the turnover rate in organizations. When workers feel happy, they will become proactive in their work. Hence, we need to consider reward as one of the effective tools to improve the productivity of the staff in the education field since recently, education industry has become one of the major contributor to the economic and social development of the state as well as carving a quality workforce development for future SCORE.

\section{Literature Review}

This research is conducted to analysis the relationship between reward and productivity in higher institutions in Sibu, Sarawak. Besides, researcher enable to build theoretical framework, analyse it content and develop the hypothesis. Where productivity as dependent and reward as an independent. In all kind of organizations, human resource is one of the most important resources of gaining competitive advantage over competitors for a firm. And this resource can be retained and optimally utilized through motivating it using different techniques among which rewards. According to Okwudili (2015), high productivity and efficiency of employees is possible with the effective exploitation of human resources through intrinsic reward strategy.

According to Rollinson (2008), there are basically two types of rewards: intrinsic reward and extrinsic reward. Intrinsic reward is defined as psychological rewards that come from the experience of work, or from being part of an organization, for example, having an opportunity to use skills and abilities, having a sense of challenge or 

conditions of work and security that individuals receive in return for their efforts. Both intrinsic and extrinsic rewards can stimulate employees to have higher levels of performance and productivity (Reio \& Callahon, 2004). Additionally, Hill, and Tande (2006) studies also found that both intrinsic and extrinsic rewards must be flexible and adapt to environmental, individual and organizational changes in order to attract and retain talented employees and improve productivity. Therefore, our existing research is intended to examine the relationship between these different types of rewards on productivity.

Efficient reward system can be a good motivator. However, inefficient reward system can lead to demotivation of the employees. According to Reio and Callahon (2004), both intrinsic reward and extrinsic reward motivate the employees and resulted in a higher productivity. Hence, Kawara (2014) recommended that the management should ensure that they provide good rewards to satisfy the needs of the employees. Furthermore, reward can enhance productivity by encouraging greater commitment to firm goals, reducing turnover, attracting higher quality workers and inspiring workers to put more effort on their work (Goldsmith, Veum, \& Darity, 2000).

\section{Review of Relevant Theoretical Models}

Based on the previous research, a general consensus among researchers concluded that rewards are important motivators in organizational overall performance (Kovach, 1995; Clark, Pia DiPaola, 2010; Sajuyigbe, Olaoye, \& Adeyemi, 2013). Several independent variables such as work content, recognition, working condition, bonus, benefits and promotions have been identified and have shown influence towards organizational performance. Therefore, the researcher intended to continue with this direction, supported in Kovach (1995), Clark (2010), and Sajuyigbe, Olaoye, and Adeyemi (2013), while the current study will employ six dimensions, divided into both intrinsic and extrinsic reward as highlighted in Rollinson (2008).

\section{Intrinsic Reward}

Intrinsic reward is referring to internal reward - psychological reward. It is driven by personal interest or enjoyment in the work itself. Examples are achievement, variety, challenge, autonomy, responsibility, personal, and professional growth. They also include status, recognition, praise from superiors and co-workers, personal satisfaction, and feelings of self-esteem (Mahaney \& Lederer, 2006). Some people believe that the most powerful reward comes from the personality of a person because it helps improve one's ability, competency, growth, knowledge and self-control. Employees are taught to be motivated to work hard to produce quality results when they have pride in their work, they believe their efforts are important to the success of the team, and their jobs are fun, challenging, and rewarding (Mahaney \& Lederer, 2006). Intrinsic reward can be used as a vital instrument in employees' performance and productivity as motivated employees are more productive, more efficient and more willing to work towards organizational goals than the employees who are experiencing a low level of motivation.

Intrinsic reward is used to provide recognition to a team for making a quality contribution. Team members may be awarded a plaque at an awards dinner to celebrate 
their success. Tokens of appreciation such as jackets, hats, or shirts with the team's name on it may be given in recognition for meeting a quality goal. This intrinsic reward can help in improving team performance. In addition, it can be very reinforcing for employees because intrinsic reward can be consumed immediately, unlike extrinsic reward that is likely to be used to pay off debts or be put in the bank for future use (Balkin \& Dolan, 1997).

\section{Recognition}

Recognition is a return on an employee's effort, dedication at works and results. It is governed by mutual respect and is expressed regularly through a host of simple gestures such as a sincere thank you, as well as symbolically through the receiving of an award. The purpose of the recognition is to motivate employee to reach specific goals or produce high quality results in the workplace. Recognition is positively related to employees' motivation and productivity. When the management gives proper recognition to the employees then their motivation level will be increased. Recognition is considered as very important in the banking sector in terms of motivation and productivity (Zargham, 2013). According to Ali and Ahmed (2009), there is a statistically significant relationship between reward and recognition respectively, also motivation and satisfaction. The study revealed that if reward or recognition that offered to employees were to be altered, then there would be a corresponding change in work motivation and satisfaction. In addition, reward also plays a vital role in determining the significant performance in job and it is positively associated with the process of motivation (Rizwan \& Ali, 2010).

\section{Work Content}

Work content is concerned about how employees are being satisfied by doing an effective job and a feeling to do something valuable and worthwhile. Apart from that, work contents also include work load, work pace and working hours. In addition, employee who lacks in interest are less likely to fully engage in the work and usually perform poorly (Ng \& Feldman, 2013). Therefore, every employee needs to know how important their role is and how their work contributes to the overall success of the organization.

\section{Working Condition}

One of the intrinsic reward which can motivate employees is working condition. Good working condition build on the fundamental strong interaction among employees is important for employee good performance. Employees who have intrinsic appreciation towards a good working condition always looking forward to come to work and build a strong communication network within the employees and employers. Communication builds trust and morale within the workers meanwhile it can help reduce turnover rate in an organization. Furthermore, high level of trusts are associated with effective teams and leadership. Therefore, high level of trust of employee towards the organization they are working would contribute to the productivity and efficiency in operations and hence maximise revenues and profits for the companies (Lau \& Lau, 2016). It will also increase the willingness of the employees to recommend it to others, enhance job satisfaction, and reduce the intention to leave the organization (CIPD, 2012). In addition, working condition also take into account of workplace comfortability and must be free of any hazards. 


Submitted: 24 July $2021 \quad$ Accepted: 28 September $2021 \quad$ Published: 31 December 2021

\section{Extrinsic Reward}

Extrinsic reward is the tangible and external reward to the individual. Example such as pay, fringe benefits, job security, promotions, private office space, and the social climate. Other examples include competitive salaries, pay raises, merit bonuses, and such indirect forms of payment as compensatory time off. Organizations are able to improve worker productivity by paying workers higher salary. Higher salary may enhance productivity by encouraging greater commitment to firm goals, reducing turnover, attracting higher quality workers and inspiring workers to put more effort on their work (Goldsmith, Veum, Darity, \& Myers, 2000). As a result, people are attracted to well-paying of the jobs as they are willing to put more effort to perform the activities (Stajkovic \& Luthans, 2001). According to Hafiza, Shah, and Jamsheed (2011), employees prefer to receive extrinsic reward than intrinsic reward because empowerment has negative effect on motivating employees. This is due to the lack of trust between employees and their boss since employees think that their boss has over burden him instead of thinking himself empowered.

\section{Bonus Payment}

Bonus payment is a reward given to inspire and motivate employees do their job well. Lotta (2012) agreed that the bonus payment reward is indeed effective in motivating employees. Moreover, Ojokuku and Sajuyigbe (2009) also found that satisfaction gained from bonus payment has a significant effect on employees' performance. However, Perry, Mesch, and Paarlberg (2006) discovered that this method has a de-motivating effect among employees. In addition, money may influence the mind set of employees to become greedy and indirectly destroy their intrinsic interest in the job (Srivastava \& Bartol, 2001). While Bishop (1987) suggested that the pay is directly related with productivity and reward system depends on the size of the organizations. Therefore, organizations nowadays is experiencing increasing competitive environment and they need to determine the reasonable balance between employees' loyalties and commitments, and performances of the organizations. On the other hand, employees who receive a miserly bonus reflects how the company assessed their performance, might consider to improve next year (Finkle, 2011).

\section{Benefits}

Benefits is another type of reward given to promote employees motivation and satisfaction in the long term. Examples of benefits are allowance, annual holidays, pension, sick leave, insurance, company cars, car loan, medical cover and payment increment. Organizational benefits can help the workers to improve their performances, reduce their stresses regarding financial difficulty and therefore they can fully focus on their works. Employees' benefits are elements of remuneration given in addition to the various forms of cash pay. According to Kibet and Kalei (2020), there is a strong relationship between employees' benefits and productivity.

\section{Promotion}

Promotion is defined as a movement to a position in which responsibilities and presumably prestige is enhanced. Promotion is given upon capabilities and good performances of employees. Promotion is an important feature of employees' career life, can affect employees' job experience levels and can have an obvious impact on other job aspects like job attachment and responsibilities (Kosteas, 2009). Organizations can 

an encouragement for them to do their superior effort. Additionally, promotion can influence the instrument of exerting better attempts, if employees put a significant value on it (Pergamit \& Veum, 1999). In addition. Promotion also provide opportunities for personal growth in terms of responsibilities and social status. Workers who perceive that promotion are a likely to experience satisfaction from their jobs. According to Nzuve (2007), promotion is a change of assignment from a job at a lower level to another at a higher level within the organization and it is a reward for employees come with an increase in pay and improved status. However, promotion can only be effective in improving job satisfaction if it is done fairly based on meritocracy must be conducted in fairness among all the employees to enhance teamwork (Alice, Garashi, Ogodo, \& Odhiambo, 2012).

\section{Conceptual Framework}

Figure 1 is a conceptual framework which contains both independent and dependent variables. As shown below, intrinsic rewards and extrinsic rewards are represented as independent variables while productivity is the dependent variable for this study. Intrinsic rewards include personal, work content, recognition, working conditions meanwhile, extrinsic rewards include payment, benefits and promotions.

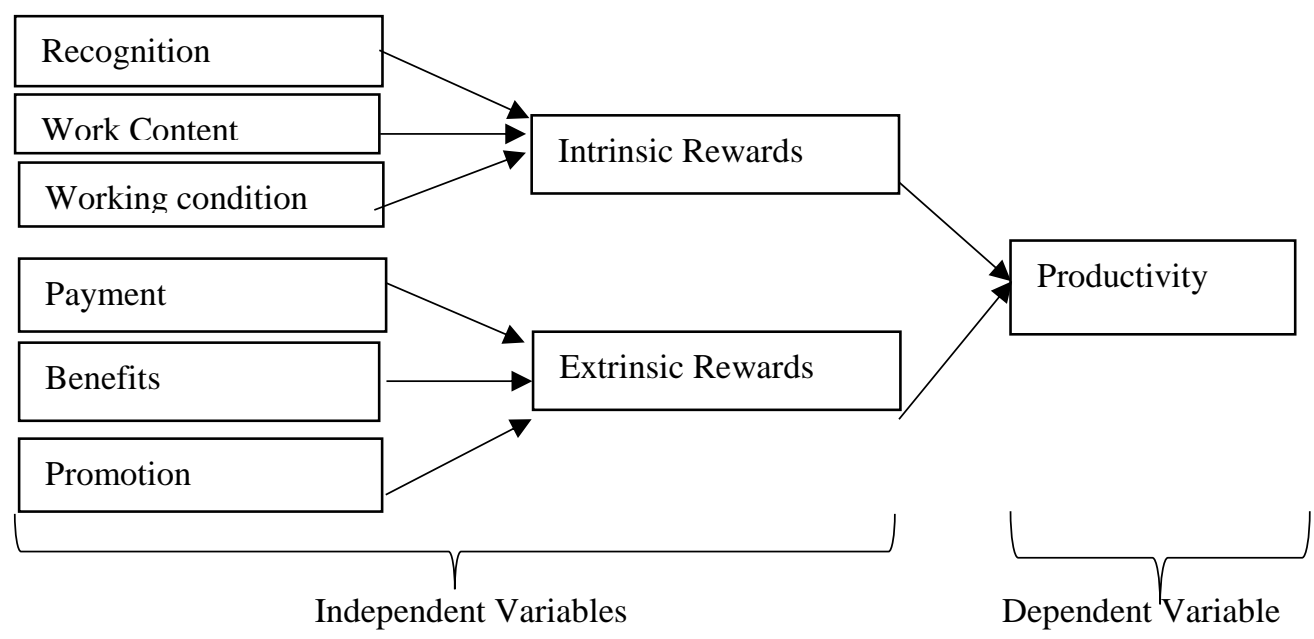

Figure 1 Conceptual framework

Source: Author

\section{Research Methodology}

Quantitative method was employed to carry out the research through survey questionnaire with employees from 4 major private higher institutions. This study only involved private higher institutions which are offering undergraduate courses within Sibu only by adopting cluster random sampling. The population size $(\mathrm{N})$ for this study is 300. According to Krejcie and Morgan (1970) the sample size required is 169. A total of 197 Sets of questionnaires were collected for analysis.

After getting management approval, a total of 300 sets of questionnaires were distributed to 4 institutions involved. Prior to the distribution of the actual survey, a pilot test was conducted on 15 respondents from one university and the results revealed that Cronbach's Alpha values for all variables were in the range of $0.65-0.70$. The 

current state of respondents' institutions. Data obtained from the survey questionnaires were then analyzed with SPSS version 23. Descriptive statistics, mean and standard deviation were employed to determine the type of rewards which employees perceived within the organizations they were working with. Likert scale of $1=$ strongly Disagree to $5=$ strongly agree were employed.

\section{Results and analysis}

This section attempts to analyze the data in answering the research questions relating to type of rewards which employees perceived with the organizations they are working.

Research Question 1 : Which types of rewards are important at the higher institutions located in Sibu?

The analysis for the higher institutions are based on two types of rewards: intrinsic rewards such as recognition, work content, working condition, and extrinsic reward such as benefit, bonus, and promotion.

\section{Table 1 : Work Content}

\begin{tabular}{llll}
\hline & N & Mean & Std. Deviation \\
\hline I am interested in what I am doing in the organization now. & 197 & 3.99 & .746 \\
I receive training which teach me something new. & 197 & 3.81 & .827 \\
I join all the activities that organized by the organization. & 197 & 3.52 & .830 \\
I understand clearly what is my responsibility. & 197 & 4.23 & .688 \\
\hline Work Content & 197 & 3.89 & .53050
\end{tabular}

Note: Cronbach alpha $=0.622 ; 0-1.66$ (low); $1.67-3.32$ (moderate); $3.33-5$ (high)

From the table, it shows that work content has high mean of 3.89 which is where it is above 3.33. Majority of the respondents clearly know what is their responsibility in their work this can help them to be more productivity. According to $\mathrm{Ng} \&$ Feldman (2013), employee who lacks in interest are less likely to fully engage in the work and usually perform poorly.

\section{Table 2 : Recognition}

\begin{tabular}{llll}
\hline & N & Mean & Std. Deviation \\
\hline I was praised by supervisor regularly. & 197 & 3.41 & .850 \\
I am respected by all my colleagues. & 197 & 3.79 & .711 \\
I get credit for what I have in my work. & 197 & 3.50 & .799 \\
I am allowed to decide on my method to do the work. & 197 & 3.79 & .732 \\
\hline Recognition & 197 & 3.62 & .53666
\end{tabular}

Note: Cronbach alpha $=0.638 ; 0-1.66$ (low); $1.67-3.32$ (moderate); $3.33-5$ (high)

From the table, it shows that recognition has a high average mean of 3.62 which is above 3.33. The result shows that most of the respondents agreed that they are allowed to decide on their method to do the work and they are respected by their colleagues this can increase their productivity. According to Zargham (2013), recognition is considered as very important in the banking sector in terms of motivation and productivity. In addition, reward also plays a vital role in determining the significant performance in job and it is positively associated with the process of motivation (Rizwan \& Ali, 2010). 


\begin{tabular}{lrcc}
\hline Submitted: 24 July $2021 \quad$ Accepted: 28 September 2021 & \multicolumn{3}{c}{ Published: 31 December 2021 } \\
\hline I am happy with my work hours. & 197 & 3.87 & .882 \\
I get the opportunity to mix with my colleagues and to communicate on & 197 & 3.93 & .725 \\
work aspect. & 197 & 4.00 & .953 \\
My working condition is physically and emotionally comfortable & 197 & 3.95 & .838 \\
I like my working environment & 197 & 3.94 & .63770 \\
\hline Working Condition & &
\end{tabular}

From the table, it shows that working condition has high average mean of 3.94 which is above 3.33. It is also indicated that working condition has the highest mean among the other variables. In addition, the result also shows that most of the employees have high level of trusts towards the organization leadership. According to Lau and Lau (2016), high level of trust of employee towards the organization they are working would contribute to the productivity and efficiency in operations and hence maximise revenues and profits for the companies.

\section{Table 4 : Bonus Payment}

\begin{tabular}{llll}
\hline & N & Mean & Std. Deviation \\
\hline I am satisfying with my company bonus scheme and incentive. & 197 & 3.15 & 1.007 \\
My salary increase consistently. & 197 & 3.18 & .976 \\
The basis of payment, for example overtime payment, is reasonable. & 197 & 3.09 & .954 \\
I receive my salary on time. & 197 & 4.09 & .862 \\
\hline Bonus Payment & 197 & 3.38 & .74984 \\
\hline
\end{tabular}

Note: Cronbach alpha $=0.797 ; 0-1.66$ (low); $1.67-3.32$ (moderate); $3.33-5$ (high)

From the table, it shows that bonus payment has high average mean of 3.38 which is above 3.33. Mean of bonus payment is slightly above 3.33 indicated that most of the respondents still perceive bonus payment as important reward and also expected organization will continue to give bonus payment as usual as a way to make employees feel happy and keep to their work. According to Lotta (2012), bonus payment reward is indeed effective in motivating employees. While Ojokuku and Sajuyigbe (2009) found that satisfaction gained from bonus payment has a significant effect on employees' performance.

\section{Table 5 : Benefits}

\begin{tabular}{llll}
\hline & N & Mean & Std. Deviation \\
\hline My company remuneration and staff benefits are good & 197 & 3.53 & .884 \\
I didn't encounter any problem with my leave application & 197 & 3.88 & .777 \\
My medical scheme is satisfactory & 197 & 3.69 & .828 \\
I am satisfying with the allowance I get & 197 & 3.27 & .867 \\
\hline Benefits & 197 & 3.59 & .63184 \\
\hline
\end{tabular}

Note: Cronbach alpha $=0.744 ; 0-1.66$ (low) ; $1.67-3.32$ (moderate); $3.33-5$ (high)

From the table, it shows that benefits has a high mean average of 3.59 which is above 3.33. Employees' benefits provided by organization can protect employees' personal wellbeing and job security including income replacement in the event of serious illness or permanent disability. Besides, it reduces the financial problem of the employee and they can focus and committed in their works. This lead to an increase in productivity and job satisfaction. According to Kibet and Kalei (2020), there is a strong relationship between employee benefits and productivity. 


\begin{tabular}{llll}
\hline Submitted: 24 July 2021 & \multicolumn{3}{c}{ Published: 31 December 2021 } \\
\hline & N & Mean & Std. Deviation \\
\hline I will be promoted within next two years & 197 & 2.86 & .787 \\
Employee are promoted in a fair and honest way & 197 & 3.23 & .972 \\
All the employees have an equal chance to be promoted & 197 & 3.30 & .962 \\
I am satisfying with my position in my organization & 197 & 3.62 & .743 \\
\hline Promotion & 197 & 3.26 & .68835 \\
\hline
\end{tabular}

Note: Cronbach alpha $=0.798 ; 0-1.66$ (low) $; 1.67-3.32$ (moderate) $; 3.33-5$ (high)

From the table, it shows that promotion has an average mean of 3.26 which is below 3.33. The result revealed that most of the employees do not have high expectation for higher position. Most of the respondents least were satisfied with their position in their organization and are happy with their current work. According to Pergamit and Veum (1999), promotion can influence the instrument of exerting better attempts, if employees put a significant value on it. Additionally, promotion is a change of assignment from a job at a lower level to another at a higher level within the organization and it is a reward for employees come with an increase in pay and improved status (Nzuve, 2007)

Research Question 2: How each type of intrinsic rewards (recognition, work content, working condition) is respectively correlated with productivity?

The Pearson correlations are employed to indicate the strength of relationships between the type of intrinsic rewards and productivity and whether they are significant at $0.01(\mathrm{p}<0.01)$. This is illustrated in the following Table 7.

\section{Table 7 : Correlations between type of intrinsic rewards with productivity}

\begin{tabular}{ll}
\hline Type of intrinsic rewards / Pearson Correlation & Overall \\
\hline Recognition & 0.292 \\
Work content & 0.377 \\
Working condition & 0.489 \\
\hline
\end{tabular}

Note: Correlation is significant at the 0.01 level ( 2 tailed)

Source: Author

Table 7 indicates intrinsic rewards such as recognition, work content and working condition are moderately high while recognition is moderately low and significantly correlated with productivity. This implies that each type of intrinsic rewards are of paramount importance in determining the organizational productivity.

Research Question 3: How each type of extrinsic rewards (bonus payment, benefits, promotion) is respectively correlated with productivity?

\begin{tabular}{|c|c|}
\hline Type of intrinsic rewards / Pearson Correlation & Overall \\
\hline Bonus payment & 0.311 \\
\hline Benefits & 0.385 \\
\hline Promotion & 0.256 \\
\hline
\end{tabular}

Table 8 indicates extrinsic rewards such as bonus payment and benefits are moderately high while promotion is moderately low and significantly correlated with productivity. This implies that each types of extrinsic rewards are of paramount importance in determining the organizational productivity. 
Research Question 4: Which type of rewards will strongly affect employee productivity?

\section{Table 9: Coefficients}

\begin{tabular}{|c|c|c|c|c|c|}
\hline \multirow[t]{2}{*}{ Model } & \multicolumn{3}{|c|}{$\begin{array}{r}\text { Unstandardized Coefficients Standardized } \\
\text { Coefficients }\end{array}$} & \multirow[t]{2}{*}{$\mathrm{t}$} & \multirow[t]{2}{*}{ Sig. } \\
\hline & $\overline{\mathrm{B}}$ & Std. Error & Beta & & \\
\hline (Constant) & 5.997 & 1.213 & & 4.943 & .000 \\
\hline Working Content & .103 & .088 & .096 & 1.169 & .244 \\
\hline Recognition & .025 & .084 & .024 & .300 & .764 \\
\hline Working Condition & .311 & .074 & .346 & 4.175 & .000 \\
\hline Bonus payment & -.006 & .070 & -.008 & -.083 & .934 \\
\hline Benefits & .129 & .089 & .142 & 1.455 & .147 \\
\hline Promotion & .025 & .067 & .030 & .374 & .709 \\
\hline
\end{tabular}

Note: Dependent Variable: Productivity

From the table, the result shows that the $\mathrm{p}$ value for working condition is 0.00 which is less than $0.05(\mathrm{p}<0.05)$ and is considered as the highest reward when 1 unit of working condition add on. It follows by benefits, 0.142 and working content, 0.096. Both promotion and recognition variables have similar beta of 0.024 per unit while bonus payment shows negative beta of 0.008 which considered as the lowest reward as compare to other variables. According to Deepak (2013), a field study conducted on 266 workers found that high pay didn't lead to statistically better performance and productivity. In other words, manager must think carefully not just about what to pay employees, but also how to pay them. Wrong method used for their bonus payment may lead to opposite result such as below productivity.

Research Question 5: What are the relationship between independent variables and dependent variables?

Table 10: Anova

\begin{tabular}{llrrrrr}
\hline Model & \multicolumn{2}{l}{ Sum of Squares } & df & Mean Square & F & Sig. \\
\hline 1 & Regression & 17.529 & 6 & 2.921 & 11.820 & $.000^{\mathrm{b}}$ \\
& Residual & 46.960 & 190 & .247 & & \\
& Total & 64.489 & 196 & & & \\
\hline
\end{tabular}

Note: Dependent Variable: Productivity, Predictors: (Constant), Promotion,

Working_Condition, Recognition, Bonus_Payment, Work_Content, Benefits

From the table, it shows that the $F$ value of 11.820 and the $p$ value is 0.00 which is less than 0.05 ( $p<0.05)$. In overall, the regression model with two type of rewards was suitable in explaining the variation in productivity where it indicated that there is a linear relationship between productivity and the reward system. Equation: Productivity=17.529 +46.960 (Rewards) indicating a unit increase in rewards system is associated with a unit increase in the average of productivity.

Table 11 : Coefficients

\begin{tabular}{lllllll}
\multicolumn{3}{c}{ Model } & & \multicolumn{3}{c}{ Standardized } \\
\cline { 3 - 5 } & & $\mathrm{B}$ & Std. Error & Beta & & Sig. \\
\hline 1 & (Constant) & 5.641 & 1.202 & & 4.693 & .000 \\
& Intrinsic Rewards & .172 & .033 & .414 & 5.157 & .000 \\
& Extrinsic Rewards & .036 & .026 & .110 & 1.369 & .172 \\
\hline
\end{tabular}


From the table, it shows that intrinsic rewards have the higher coefficient beta of 0.414 per 1-unit compared to extrinsic reward is 0.110 per unit increase. The table also shows that intrinsic is more significant with productivity $(\mathrm{p}<0.05)$. It also means intrinsic reward can affect the productivity of the employee in higher Institutions. Meanwhile, extrinsic reward has a significant value more than 0.05 ( $p>0.05)$ and have no significant with productivity. This result is consistent with the findings from Perry et al (2006) and Srivastava (2001) that financial reward is not a strong motivating tool.

Table 12: Results summary

\begin{tabular}{lcccccc}
\hline Variables & $\begin{array}{c}\text { Cronbach's } \\
\text { alpha }\end{array}$ & Mean & $\begin{array}{c}\text { Standard } \\
\text { deviation }\end{array}$ & $\begin{array}{c}\text { Correlation } \\
\text { value }\end{array}$ & $\begin{array}{c}\text { Standardized } \\
\text { Coefficients }\end{array}$ & $\begin{array}{c}\text { Standardized } \\
\text { Coefficients }\end{array}$ \\
\hline Intrinsic rewards & & & & & & \\
Work content & 0.622 & 3.89 & 0.5305 & 0.292 & 0.096 & 0.414 \\
Recognition & 0.638 & 3.62 & 0.5366 & 0.377 & 0.024 & 0.110 \\
Working condition & 0.738 & 3.94 & 0.6377 & 0.489 & 0.346 & \\
Extrinsic rewards & & & & & & -0.008 \\
Bonus & 0.797 & 3.38 & 0.7498 & 0.311 & 0.142 & \\
Benefits & 0.744 & 3.59 & 0.6318 & 0.385 & 0.300 & \\
Promotion & 0.798 & 3.26 & 0.6883 & 0.256 & & \\
\hline
\end{tabular}

Source: Author

\section{Theoretical and Managerial Implications}

Based on the objective of this study, the following implications has been derived. First, the findings have shown that employees' perception rewards were moderate high in private higher institutions. This implies that most of the employees have recognized the importance of intrinsic and extrinsic rewards which can affect their productivity. Therefore, creating unique and rewarding opportunities is the best way to motivate the employee in the workplace (Kolbenschlag, 2014).

Second, the result also showed that working condition is considered the highest contributor in relation with productivity. This also implied that most of the employees were not contented with the reward system exist in their organization. According to Deepak (2013), there are other non-monetary incentives which can become powerful motivators of behaviors in the workplace,

Third, the analysis also indicated that bonus payment is significantly low with productivity and even have negative beta impact to productivity. It indicates that bonus payment bring negative correlation to productivity in higher institutions. According to Perry et al (2006), method of payment has a de-motivating effect among employees. In additional, Srivastava, Locke, and Bartol (2001) also found that bonus payment may influence the mindset of employees to become greedy to money and which indirectly destroy their intrinsic interest in the job. It was noted that that bonus payment in higher institution has a lowest value comparing to other industries and it could be due to the reason that the organization may not have the clear and transparent policy in regard to bonus payment. In additional, according to the analysis, most of the respondents have a low perception on their organizations' bonus scheme. Another reason is probably due to the culture elements of the organization leadership where the power distance is rather high. This indicated that employee does not dare to challenge their leaders and have to follow the organization's policies although they were not really contented with the policies. Moreover, they need to follow their leaders decision and accept what the 
leaders decision on the reward payment otherwise it may seems as not committed to the organization.

Meanwhile, working condition shows the highest value among the other rewards and most of the respondents agreed and satisfy with the organization working condition. One of the reason is because organization adopted a flexible time working system where employees are given the freedom to plan for their works at flexible way. Besides, the office of the employee is near to each other and they have more chances to mix and interact with their colleagues. Therefore, organization needs to maintain the existing working environment so that trust can be developed among employees. When trust existed among the employees, it would directly promote teamwork and productivity. The findings also indicated that future information leaders and managers should recognize that intrinsic factors play a bigger role in employee motivation and put more effort into creating a culture of respect, recognition, trust, and autonomy when tailoring their management strategies to tap into the emotions of their coworkers. These intrinsic motivators are more important to staff than extrinsic factors such as money (Rajesh, 2016)

Moreover, work contents and benefits need to further improve since both have low value in relation to productivity. In term of benefits, we can see that most of the respondents do not satisfy with organization's allowance. Hence, in order to increase the satisfaction, organization can consider establish a more transparent allowance policy where all the employees can participate in giving a better ideas and improvement from time to time. In this regard, employees is the most important asset in organization and therefore, they must be seen as important contributor in the organizational long term development.

Lastly, promotion and recognition have the lowest value in relation to productivity. The result indicated that respondents' perception toward promotion in this study are low and it could be attributed to the reason that most of the respondents are relatively younger group (between 20-30 age) with less than 5 years working experiences. In the past, high position in the organization normally comprised of elder persons with extensive working experiences and it could be one of the reason that organization concerned are not ready to promote employees who have less experience in working. Moreover, majority of the respondent comprised of academic staff and fresh graduates. Therefore, it is necessary for organization to understand the career development of younger generations in order to build an appropriate mechanism to meet those expectations and retain these group of talents. To achieve this, organization leaders must provide strong support to ensure these young talents can be retained in the long term.

\section{Conclusion}

According to the result, we can concluded that intrinsic rewards are higher than extrinsic rewards in higher education institutions in Sibu, Sarawak. According to Özutkua (2012), intrinsic reward is better performance indicators compare to extrinsic rewards. In view of the findings, the higher institutions at the local should have put more efforts to promote intrinsic rewards such as giving recognition, create challenging work content and exercise minimum supervision with conducive working environment in order to improve their employees' productivity which was evidenced by respondent age where majority of them are in between 20 to 30 years old with less than 5 years experiences. These group of young employees prefer to work independently under high trust 

also need to improve extrinsic rewards. A transparent and competent reward system is a paramount important to ensure all employees are able to see a fair and equitable rewards parallel with their good performances. This would lead to job satisfaction and loyalty in the long term.

\section{Further Research Directions}

This study is also subjected to some limitations. First of all, this study is based on a small sample size since it only a few private higher institutions in Sibu, Sarawak. Second, several other factors which may impact on employee productivity have not been considered in the study since our work become more volatile and continue to change with the vast amount of internal and external factors that continue impact every employees' life (Clark, Pia DiPaola, 2010). The current stress caused by covid-19 pandemic placed on employees has forced many individuals focus more on the extrinsic factors such as wages and benefits rather than intrinsic reward factors. Given these limitations, future research might need to carry out in two directions. First, other government based colleges and universities in Sarawak to be included in the future study. Second, future studies could also look into the possible inclusion of other factors such as impact of pandemic on job, personal characteristics, personal loyalty in relation to reward and productivity.

\section{References}

Ali, R. \& Ahmed, M.S. (2009). The impact of reward and recognition programs on employee's motivation and satisfaction: an empirical study. International Review of Business Research Papers, 5(4), 270-279.

Alice, S.R., Garashi, H.M., Ogodo, M.J.N., \& Odhiambo, O. (2012). Perception of civil servants towards promotion on merit", American International Journal of Contemporary Research, 2(9), 48-54.

Akhtar, C.S., Aamir, A., Khurshid, M.A., Abro, M.M.Q., \& Hussain, J. (2015). Total Rewards and Retention: Case Study of Higher Education Institutions in Pakistan. Procedia Social \& Behavioural Science, 210(2015), 251-259

Balkin, D. \& Dolan, S. (1997). R ewards for Team Contributions to Quality. Journal of Compensation \& Benefits, 13(1), 41-47.

Bishop, J. (1987). The recognition \& Reward of Employee Performance. Journal of Labor Economics, 5(4), 36-56.

Boyens, M. (2007). Organizational Socialization, Career Aspirations and Turnover Intentions among Design Engineers. Leadership and Organization Development Journal, 26(6), 424-441.

Cappelli. (2008). Talent management for the $21^{\text {st }}$ century. Harvard Business Review, 86(3), 74-81

CIPD. (2012). Where has all the trust gone Research Report, March, 2012.

Clark, P.D. (2010). Employee Motivation Factors: A Reexamination of Kovach's Study 10 Years Later. Business Masters, paper 1, Fisher Digital Publication.

Deepak, M. (2013). Do Employees Work Harder for Higher Pay? Harvard Business School. Retrieved from https://hbswk.hbs.edu/item/7287.html. 
Submitted: 24 July $2021 \quad$ Accepted: 28 September $2021 \quad$ Published: 31 December 2021

Furtado., Aquino., \& Meira. (2012), Improving organizational performance through Reward Systems, Business Dynamics in the 21 st Century, Dr. Chee-Heong Quah (Ed.), ISBN: 978-953-51- 0628-9, InTech.

Finkle, L. (2011). Motivating employee performance Through Year End Bonuses. Retrieved from https://ezinearticles.com/?Motivating-Employee-PerformanceThrough-Year-End-Bonuses\&id=5658825

Greenberg, P. (2003). Management (Tasks, Responsibilities and Practices), London Pan Books Ltd.

Goldsmith, A.H., Veum, J., \& Darity, W. (2000). Working hard for the money? Effciency wages and worker effort. Journal of Economy Psychology, 21(4), 351-385.

Hafiza, N.S., Shah, S.S., \& Jamsheed. (2011). Relationship between rewards and employee's motivation in the non profit organizations of Pakistan. Business Intelligence Journal, 4(4), 327-334.

Hill, B. \& Tande, C. (2006). Total rewards : The employment value proposition. Workspan, 10(6), 19-22.

Irabor, I.E. \& Okolie, U.C. (2019). A review of employees' job satisfaction and its effect on their retention. Economic Series, 19(2), 93-114.

Johnson, J.T., Griffeth, R.W., \& Griffin, M. (2000). Factors discriminating functional and dysfunctional salesforce turnover. Journal of Business \& Industrial Marketing, 15(6), 399 - 415.

Kawara, P. (2014). Effects of reward systems on employee productivity in Catholic University of Eastern Africa. International Journal of Recent Research in Commerce Economics and Management, 1(2), 1-4.

Krejcie, R.V \& Morgan, D.W. (1970). Determining Sample Size for Research Activities. Educational and Psychological Measurement, 30, 607-610.

Kibet \& Kalei. (2020). The Impact of employee benefits on the employee productivity at Kenya Tea Packers. International Journal of Management Studies and Social Sience Research, 2(4), 246-254.

Kovach, K.A. (1995). Employee motivation: Addressing a crucial factor in your organization's performance. Employment Relations Today, 93-107.

Kosteas, V. (2009). Job level changes and wage growth", International Journal of Manpower, 30(3), 269-284

Kolbenschlag, B. (2014). Three things that can make employees more productive. Forbes. https://www.forbes.com/sites/unify/2014/04/17/avoiding-data-disaster3-ways-to-prepare-your-contact-centers/?sh=356686d518ae.

Lau, H.S. \& Lau, H. L. (2016). Exploring organizational trust among employees of three companies in the Sarawak Corridor Renewable Energy (SCORE) region. International Journal of Business, Economics and Law, 9(3), 1-9.

Lotta, L. (2012). The impact of financial and non- financial rewards on employee, thesis, Turku University of Applied Science.

Luthans \& Doh. (2018). Culture, Strategy and Behavior in International Management, $10^{\text {th }}$ edition, McGraw-Hill

Mahaney, R.C. \& Lederer, A.L. (2006). The Effect of Intrinsic and Extrinsic Rewards for Developers on Information Systems Project Success", Project Management Journal, 37(4), 42-54.

Mello. (2014). Strategic Human Resource Management, $4^{\text {th }}$ edition, Cengage Learning. 
Submitted: 24 July $2021 \quad$ Accepted: 28 September $2021 \quad$ Published: 31 December 2021

Ng, T.W.H. \& Feldman, D.C. (2013). Does longer job tenure help or hinder job performance", Journal of Vocational Behaviour, 83(3), 305-314.

Nzuve, S.N.M. (2007). Management of Human Resources. A kenya perspective, 4 edition, Nairobi: Basic Modern Management Consultants

OECD (2015). The future of productivity. www.oecd.org/economy/growth/OECD2015-The-future-of-productivity-book.pdf

Ojukuku, R.M. \& Sajuyigbe, A.S. (2009). Effect of pay satisfaction dimensions on job performance in selected tertiary institutions in Osun State, Nigeria. African Journal Institute and Development, IV(I\&II), 86-95.

Okwudili, B.E. (2015). Effect of Non-Monetary Rewards on Productivity of Employees Among Selected Government Parastatals In ABIA State, Nigeria. Journal of Business and Management, 17(2), 6-11.

Ongori. (2008). A review of the Literature on Employee Turnover. African Journal of Business Management, 1(3), 49-54.

Özutkua. (2012). The Influence of Intrinsic and Extrinsic Rewards on Employee Results: An Empirical Analysis in Turkish Manufacturing Industry. Business and Economics Research Journal, 3(3), 29-48.

Pergamit, M.R. \& Veum, J.R. (1999). What is a Promotion? Industrial and Labor Relations Review, 52(4), 581-601.

Perry, J.L., Mesch, D., \& Paarlberg, L. (2006). Motivating Employees in a New Governance era: The performance paradigm sfifted. Public Administration Review, 66(4), 505-514.

Reio, T.G. \& Callahon, J.L. (2004). Affect, curiosity, and socialization-related Learning; a path analysis of antecedents to job performance. Journal of Business and Psychology, 19(1), 3-22.

Rensis. (1932). A technique for the measurement of attitudes. The Science Press.

Rhoades, L. \& Robert, E. (2002). Perceived organizational support: A review of the literature. Journal of Applied Psychology, 87(4), 698-714.

Rizwan, Q.D. \& Ali, U. (2010). Impact of reward and recognition on job satisfaction and motivation. An empirical study from Pakistan. International journal of business and management, 5(2), 159-167.

Rollinson, D. (2008). Organizatinal Behaviour and and Analysis: Integrated Approach, $4^{\text {th }}$ edition. Pearson

Rajesh, S. (2016). The Impact of Intrinsic and Extrinsic Motivators on Employee Engagement in Information Organizations. Journal of Education for Library and Information Science, 57(2), 197-206

Sajuyigbe, A.S., Olaoye, B.O., \& Adeyemi, M.A. (2013). Impact of reward on employees performance in a selected manaufacturing companies, in Ibadan, Oyo state, Nigeria. International Journal of Arts and Commerce, 2(2), 27-32.

Srivastava, A., Locke, E.A., \& Bartol, K.M. (2001). Money and Subjective Well-Being it's. Journal of Personality and Social Psychology, 80(6), 959-971.

Stajkovic, A.D. \& Luthans, F. (2001). Differential Effects of Incentive Motivators on Work Performance. Academy of Management Journal, 44(3), 580-590.

Thomas, L.T. \& Ganster, D.C. (1995). Impact of family-supportive work variables on work-family conflict and strain: A control perspective. Journal of Applied Psychology, 80(1), 6-15. 
Ugboro, I.S. \& Obeng, K. (2000). Top management leadership, employee empowerment, job satisfaction, and customer satisfaction in TQM organizations: an empirical study. Journal of Quality Management, 5(2), 247-272.

Walters, Bamidele, Emmanuel, Nwanneka., \& Bennedict. (2019). Effect of reward system on employee performance among selected manufacturing firms in the Litoral region of Cameroon. Academic of Strategic Management Journal, 18(3), $1-16$.

Zargham, U.K. (2013). To measure the relationship between Reward, 3rd International Conference on Management, Economics and Social Sciences.

Zunnoorain, Khan., Karim, N., \& Sharif, U.J. (2014). Role of performance based reward system. City University Research Journal, 4(1), 80-87. 